\begin{tabular}{|c|c|c|}
\hline & Int.J.Curr.Microbiol.App.Sci (2016) 5(11): 867-876 & \\
\hline & International Journal of Current Microbiology and Applied Sciences & 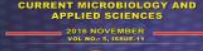 \\
\hline & ISSN: 2319-7706 Volume 5 Number 11 (2016) pp. 867-876 & \\
\hline $\begin{array}{l}\text { EXCELLENT } \\
\text { PUBLISHERS }\end{array}$ & & (1) \\
\hline
\end{tabular}

Original Research Article

http://dx.doi.org/10.20546/ijcmas.2016.511.099

\title{
Effect of Spent Laptop Battery Waste on Soil Microorganisms
}

\author{
Douglas, Salome Ibietela* and Nwachukwu, Eucharia Uche
}

Department of Microbiology, Rivers State University of Science \& Technology, P.M.B. 5080, Nkpolu-Orowurukwu Port Harcourt, Rivers State, Nigeria

*Corresponding author

Keywords

Spent batteries,

E-waste,

inhibitory,

stimulatory,

Resistant.

Article Info

Accepted:

20 October 2016

Available Online:

10 November 2016

\section{A B S T R A C T}

The research was carried out to investigate the effect of spent laptop battery on soil bacterial and fungal populations. A stock solution of the battery was prepared by soaking the laptop batteries for six months in sterile distilled water. Various concentrations of the toxicant; $12.5,25.0,50.0,75.0$ and $100 \mathrm{ml}$ were added to the soil samples. Samples were taken out of each setup for analyses at intervals of: 0, 7, 14, 21 and 28days with unpolluted soil samples to serve as control. The soil samples were analyzed for total heterotrophic bacterial and fungal counts. The results showed that the toxicant concentrations do not have significant effect on bacterial populations when compared with control, while for the fungal communities there was a general decrease in population from days 0 to 28 , and significant difference between the higher concentrations and that of the control. At the beginning of this study; day zero, the following fungal genera were isolated and identified: Penicillium, Cladosporium, Fusarium, Rhizopus, Mucor, and Aspergillus while at Day 28 only Aspergillus niger and Fusarium sp were seen in the lowest toxicant concentration. It was also observed that, the fungal populations were more inhibited by the toxicant, while the bacterial populations were more resistant. It is important to note that, continuous disposal of batteries into the soil environment can cause detrimental effects, not only to man, but also to other living things and the microbial populations on which other life forms depends for their activities. This could in turn bring about ecological imbalance, retard decomposition processes and other biochemical and metabolic activities carried out in the soil by these organisms.

\section{Introduction}

With the current trends in technological advancement, and newest discoveries in information and communication technology, laptops have become a part of everyday life. Laptops are electronic devices which are used by man, in all spheres of daily life to make work easier. With the increase in the demand and consumption of these electrical and electronic devices some become obsolete and nearing the end of its useful life (Mohan and Chaithanya, 2015). The increased demand results in the production of very large amount of these wastes annually. These wastes are referred to as Ewaste or electronic waste, which includes computers (laptops), mobile phones, 
television sets, office equipment, refrigerators etc. Due to the population of Nigeria, the domestic consumption of these devices is on the increase which in turn leads to the growing volumes of these wastes. And Nigeria is the highest producer of this waste in West Africa (Manhart et al., 2011). Introducing these wastes in large volumes, without proper environmental management system in place, these wastes could impact the environment (including microorganisms, plants and animals), the populace and the economy at large (Manhart et al., 2011). Most times, people prefer to buy new electronic device when their old device go bad, rather than repairing a faulty one, even when their devices have reusable parts (Babu et al., 2007). The electronic waste, contain components which are hazardous this may pose serious environmental concerns when they are disposed off without adequate treatment. And batteries are grouped as hazardous waste which makes their disposal regulated. Most of the batteries in use are classified as either secondary: Nickel-cadmium, nickel metal hydride, lithium-ion, and lead-acid batteries are rechargeable, and are more heavily used in commercial settings than the primary batteries, mostly non-rechargeable (Green, 2005).

Batteries are used as backup or direct power to IT systems and networks and these uninterrupted powers are very important for proper functioning of the IT equipment and networks (Frost and Sullivan, 2004). The battery industry has put in great efforts overtime to recycle and replace toxic components of these electronic materials. Even with these efforts spent batteries still fall under hazardous waste and they include; "rechargeable nickel-cadmium batteries, silver button batteries, mercury batteries, small sealed lead-acid batteries, and alkaline batteries"' (Green, 2005).
Unfortunately the effects of laptop batteries on the environments are negative. As when these batteries are burned or incinerated with other waste, the fumes pollute the air. "When they are released into the aquatic environment, they pollute our water bodies and when thrown into 'dump' areas their toxic ingredients are left to seep into the soil, finally to groundwater, causing massive and devastating damage to our natural ecosystem" (Green, 2005). The toxic components in these batteries are leached into the groundwater when improperly disposed of. Some metals that are especially toxic to aquatic organisms and humans are mercury, lithium, cadmium, chromium, and lead (U.S. EPA, 2004a).

When introduced into the environment, chemical components from the batteries regardless of the type lead to the selective pressure of species which are resistant to their harmful effects. Soil contamination with batteries limits the microbial biodiversity, but it also increases the abundance of some bacteria species which are more resistant to changes in the environmental homeostasis, (Landi, 1993). Battery components can inhibit the growth of certain microorganisms by interfering with enzymatic activity, like the inhibition of Nitrogenase actively involved in Nitrogen fixation (Jastrzebska, 2006). The inhibition of Nitrogenase actively can reduce the amount of nitrogen available for plants, thus reducing crop yield. Other important microbial processes in the soil like: nutrient transformation, degradation and decomposition of resistant components of plant and animal tissues, bioremediation, humus formation, surface blooming to reduce erosion losses, all which depends on the equilibrium found among the different groups of microorganisms present in the soil environment, which are in turn affected when high concentrations of these toxic 
waste are present (Rangaswami, 2004). When the toxic components are found in the soil, they affect the presence of the soil microbial enzymes which are required for the above processes and for organic matter turnover. Key enzymes affected in the soil are dehydrogenase (play a very essential role in the process of organic matter oxidation. This study is aimed at evaluating the effect of spent laptop battery on soil microorganisms, achieved by determining the effect of concentrations and exposure time of the toxicant on the soil bacterial and fungal populations. Also, to evaluate which of the microbial group is most sensitive to the toxicant, therefore more suitable as instrument for bioassay.

\section{Materials and Methods}

\section{Source of Spent batteries}

Used laptop batteries were bought from the phone and laptop market, at the Ogbunabali, Garrison area of Port Harcourt. Two sets of the brand of battery packs were forced opened aseptically, and the cells were soaked in $200 \mathrm{ml}$ sterile distilled Water in a $500 \mathrm{ml}$ Erlenmeyer flask for six months. This served as the stock toxicant.

\section{Collection of soil Samples}

Soil samples were collected from the school farm where there is no history of such pollution. Three soil samples were collected using soil auger; this was done at a depth of about $15 \mathrm{~cm}$ deep and $1 \mathrm{~m}$ apart and missed together for homogeneity(Douglas and Green, 2015). The soil samples were put in sterile plastic bags and taken to the departmental laboratory. After sieving the soil, $500 \mathrm{~g}$ of soil was weighed and put in 12 containers, labelled A to $\mathrm{F}$, in duplicate. Various concentrations of the toxicants; $100 \mathrm{ml}, \quad 75 \mathrm{ml}, 50 \mathrm{ml}, 25 \mathrm{mland} 12.5 \mathrm{ml}$ respectively, in plates $\mathrm{A}$ to $\mathrm{F}$ were added to the soil samples in duplicates and missed thoroughly. Plate F is the control, without toxicant (Table 1).

\section{Microbiological analysis of the soil Samples}

\section{Total Heterotrophic Bacterial counts}

This was done using the spread plate method. One gram (1g) of soil sample was removed aseptically from each plate, and dispensed into $9 \mathrm{ml}$ of sterile normal saline. This was serially diluted to $10^{-4}$, this procedure was done for all samples. With a sterile pipette, $0.1 \mathrm{ml}$ aliquot was dropped on the surface of sterile Nutrient agar plate, this was done in triplicate for each dilution, then spread using a sterile glass spreader. Plates were incubated at temperature of $37 \pm 2{ }^{\circ} \mathrm{C}$ for 24 hours ( Douglas and Green, 2015). Plates were brought out and counted after 24hours, then mean values calculated. Morphologically un-identical colonies were picked randomly and further purification done by sub-culturing on fresh nutrient agar. Pure cultures were "analysed; culturally, biochemically and identified based on the identification in the Manual for Determinative Bacteriology" (Holt et al., 1994).

\section{Total Heterotrophic Fungal Counts}

Potato dextrose agar (PDA) with tetracycline added was used for isolation and enumeration of total heterotrophic fungi. The Tetracycline is added to prevent bacterial growth while selectively permitting the isolation of yeasts and moulds(Douglas and Green, 2015). With a sterile pipette, $0.1 \mathrm{ml}$ aliquot was dropped on the surface of sterile Potato dextrose agar plate, done in triplicate for each dilution and spread using a sterile glass spreader. Plates were 
incubated at temperature of $37 \pm 2^{0} \mathrm{C}$ for 24 hours (Douglas and Green, 2015). Plates were brought out and counted, then mean values calculated. Morphologically unidentical colonies were picked randomly and further purified by sub-culturing. Purified fungal isolates were further analysed using lactophenol stain and observed under X10 and 40 objective lenses (Obire et al., 2008).

\section{Statistical Analysis}

The data obtained were analysed using the single factor ANOVA and Regression analysis. This was used to compare the effect of the spent battery waste on the bacterial and fungal communities. That is the treatment sample and the control to determine if there is any significant statistical difference in the data obtained.

\section{Results and Discussion}

A total number of nine (9) bacterial genera were identified and they include; Staphylococcus, Bacillus, Pseudomonas, Enterobacter, Micrococcus, Serratia, Acinetobacter, Escharichia coll, and Alcaligenes. Six (6) fungal genera were also identified and they include; Rhizopus, Aspergillus, Fusarium, Cladosporium, Mucor, and Penicillium, from the soil samples. The total heterotrophic bacteria count ranged from $2.9 \times 10^{5}$ to $8.2 \times$ $10^{7} \mathrm{cfu} / \mathrm{g}$ for bacteria, while the fungal Isolates ranged from $1.2 \times 10^{1}$ to $2.7 \times 10^{5} \mathrm{sfu} / \mathrm{g}$. Some species were more sensitive to the battery waste than the others. The bacterial communities were least affected, when compared with the fungal population. All bacterial genera isolated from day zero were seen throughout the study period, but there was a decrease in population. While out of the six fungal genera isolated and identified in day0, only two genera; Aspergillus and Fusarium survived in the least toxicant concentration of $12.5 \mathrm{ml}$ at Day 28. The highest populations of total heterotrophic bacterial counts obtain from the soil sample were from the samples E with $12.5 \mathrm{ml}$ toxicant and sample $\mathrm{F}$ which is the control. This shows that the bacterial communities were more resistant to the toxicant, but effective against the fungal species because the growth of fungal species was inhibited. It was observed that, fungal species decreased with increase in concentration and exposure time (Figures $1-6$ ), so that at the end of Day28 only Aspergillus niger and Fusarium sp occurred throughout the study period (Table 2).

Microorganisms play a very important role in primary production, biogeochemical cycles (cycling of nutrients), and decomposition of organic matter both in the terrestrial and aquatic environments. Therefore, the presence of spent battery waste in the soil environment may impair microbial species and may subsequently impact on soil microorganisms. Spent battery waste, whose main components are heavy metals may affect microorganisms through leaching due to improper disposal and the structure and function of the microbial ecosystem, may be impaired by the toxicity of the components. The presence of these toxic components may result in the production of both morphological and physiological changes in the microbial populations, which may in turn affect the composition of species in that environment (Baldrian, 2009).

The effect of the toxicant concentration on soil microorganisms shows that some of the organisms like the bacterial populations were able to tolerate (resistant) all concentrations of the toxicant used. But some of the fungal genera including Penicillium, Rhizopus, Cladosporium, and Mucor, were inhibited, at all concentrations 
of the toxicant. The control soil sample (FF, no toxicant) maintained constant population of all the species observed from Day 0 . Therefore, the colony counts come fairly stable within a certain range. This shows that some organisms are resistant to the heavy metals present in the toxicant. While on the other hand, the fungal populations were more affected than the bacterial population by the toxicant. It was observe that the toxicant concentrations were stimulatory for the bacterial population rather than inhibitory. Since the bacterial counts tends to increase even with increase in toxicant concentrations. The results showed that there was no significant difference between the counts in the control and that of even the highest toxicant concentration in bacterial set up, while comparing growth in the fungal population showed that there was a significant difference in the growth of fungal population when compared with the highest concentrations and the control growth form Days 0 to 28. Therefore, the fungal populations were more affected by the spent battery than the bacterial populations. Resistance of bacterial population to heavy metals had been reported by previous researchers, who observed that when bacterial population was introduced into heavy metals, Bacillus sp and Alcaligenes sp were shown to be resistant to the toxicity of the heavy metals Odokuma and Ijeomah (2003). The resistance exhibited by these isolates in the presence of the respective heavy metal salts may be due to the possession of heavy metals resistant plasmids (Odokuma and Oliwe, 2003). While for the Bacillus sp, the resistance may be due to its spore forming ability, which may have also contributed to its ability for survival when exposed to the various heavy metals found in the toxicant. Pseudomonas $\mathrm{sp}$, is resistant to many toxicants because of its use of diverse substrates (organic and inorganic) as carbon source. Also, its genetic machinery, cell wall complexity, as Gramnegative organism may have contributed to its resistance. "Similar reasons can also be advanced for the resistance of Serratia sp to toxicity of the various heavy metals introduced into the soil samples". All the nine isolates were observed to be resistant to the components of the battery, at the concentrations used. The bacterial counts were not significantly affected when compared with that of the fungi. The introduced toxicant seems not to decrease the bacterial counts, although the control soil still has more counts than the toxicant polluted soil samples. Therefore, it is important to further analyze the toxicant to see if it contains other nutrient elements like; Nitrogen and Phosphorus as components which would support microbial growth. And since Pseudomonas sp, Bacillus sp, Staphylococcus sp, Alcaligenes sp, Serratia sp, Enterobacter sp, Escherichia coli, Acinetobacter sp and Micrococcus sp were present throughout the study period. These isolates can be used for heavy metal remediation through accumulation. Research has also shown that a correlation exist between metal tolerance and antibiotic resistant in bacteria. This may be due to the likelihood that the resistance genes both to antibiotics and heavy metals may be situated in close proximity on the same plasmid in the bacterial cell and hence, likely to be moved together in the environment(Spain, 2003). Just as care is taken to avoid overuse of antibiotics, to prevent antibiotic resistant, same caution should be exercised in the introduction of the heavy metals into the environment. Fungal genera may also differ in their response to heavy metals, which could be as a result of their cellwall structure and chemistry, and also, biochemical and physiological properties (Sosak-Swiderska, 2010). 
Table.1 Experimental Design

\begin{tabular}{lll}
\hline Experimental Set up & Test Experiment & Toxicant Concentration(ml) \\
\hline A & 500g of soil & 100 \\
B & 500g of soil & 75 \\
C & $500 \mathrm{~g}$ of soil & 50 \\
D & 500g of soil & 25 \\
E & 500g of soil & 12.5 \\
F & 500g of soil & No toxicant \\
\hline
\end{tabular}

Table.2 Occurrence of Fungal Isolates throughout the Study Period

\begin{tabular}{|c|c|c|c|c|c|}
\hline $\begin{array}{ll}\text { Identified Fungi } \\
\text { Isolates }\end{array}$ & Days 0 & Days 7 & Days 14 & Days 21 & Days 28 \\
\hline Aspergillus $\mathrm{sp}$ & + & + & + & + & + \\
\hline Penicillium sp & + & + & + & + & - \\
\hline Mucor sp & + & + & + & - & - \\
\hline Rhizopus sp & + & + & - & - & - \\
\hline Cladosporium sp & + & + & + & - & - \\
\hline Fusarium sp & + & + & + & + & + \\
\hline
\end{tabular}

Key: +; that is observed, - that is not observed

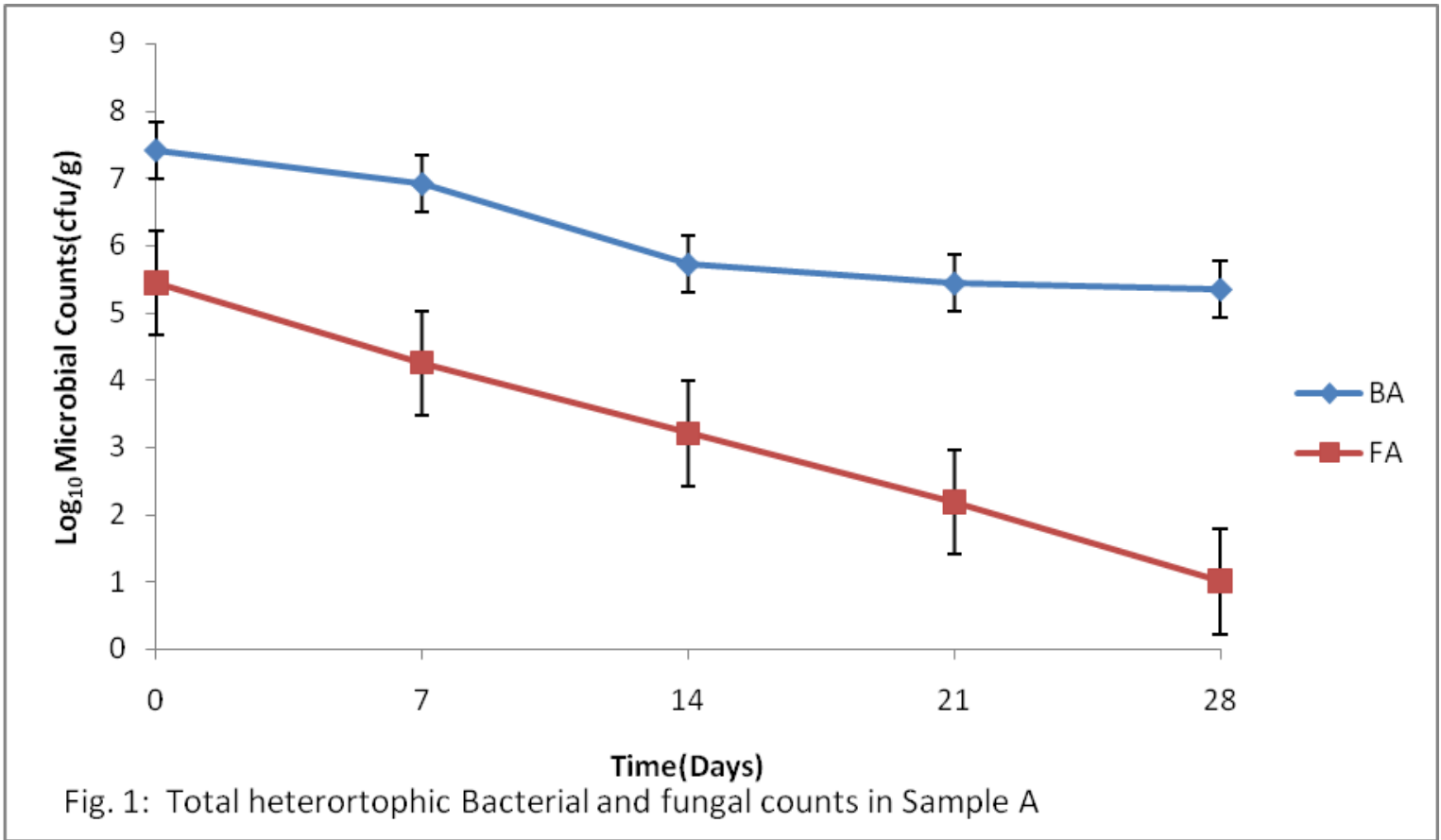




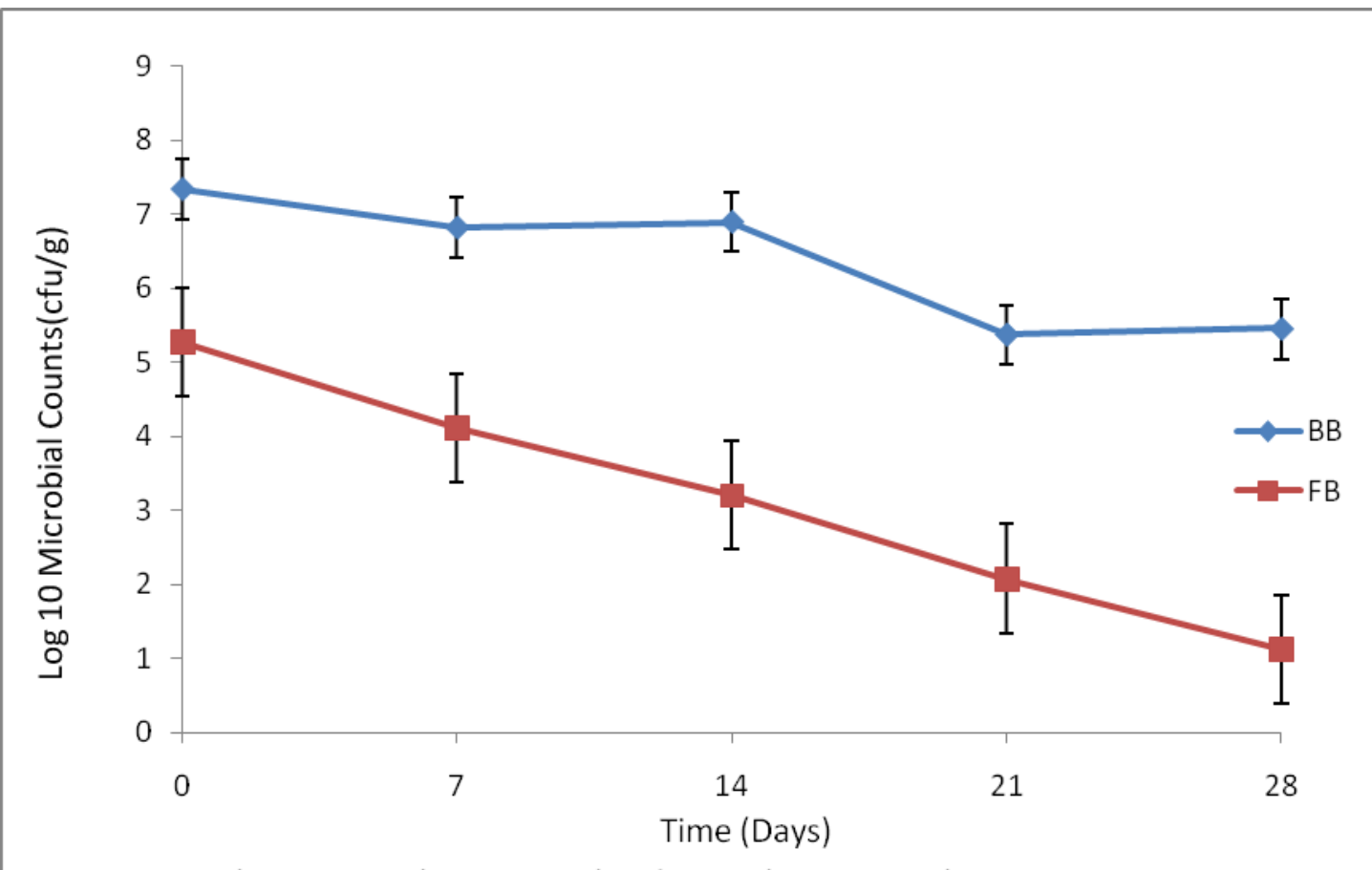

Fig. 2: Total Heterotrophic Bacterial and Fungal counts in Plate B

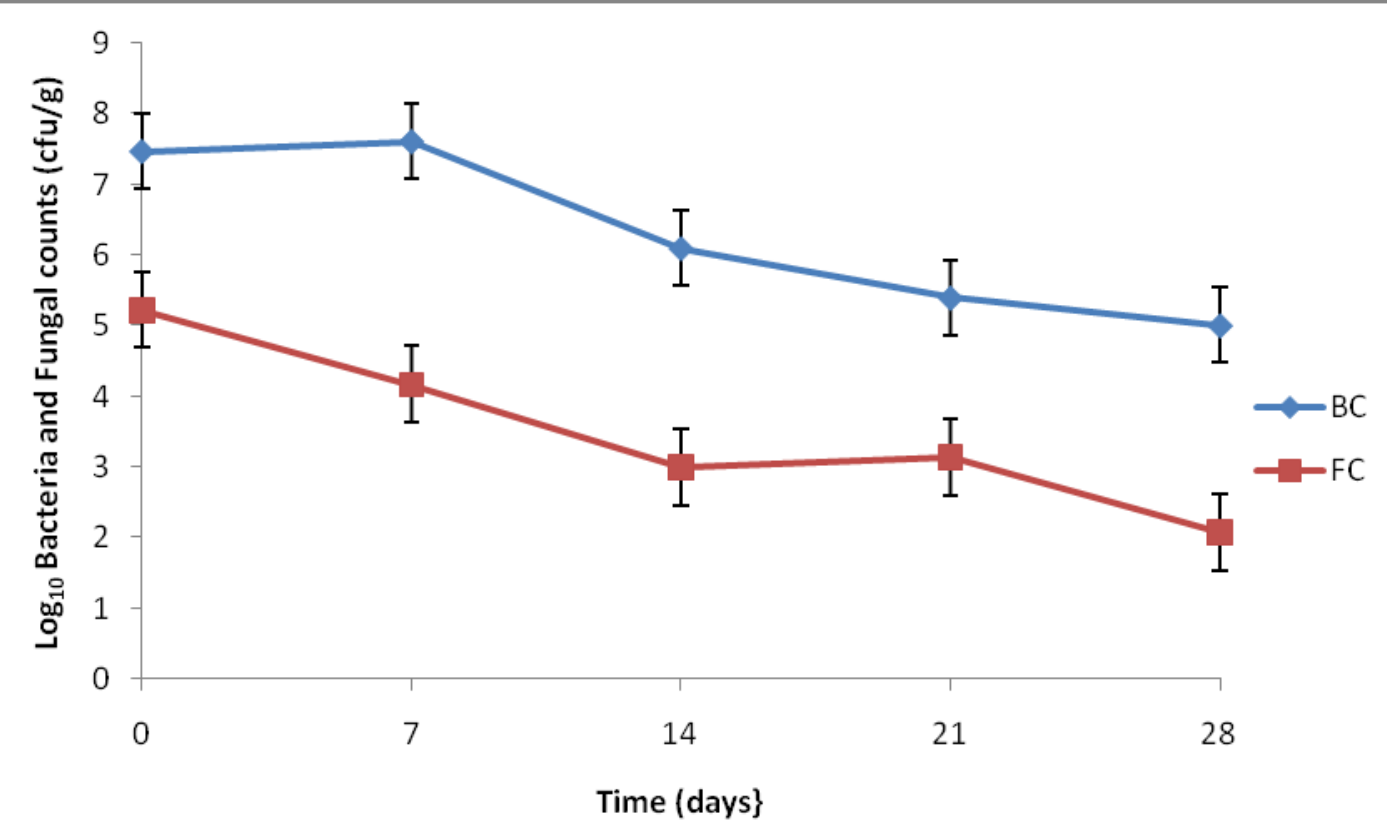

Fig.3: Total Heterotrophic Bacterial and Fungal counts in Plate C 
Int.J.Curr.Microbiol.App.Sci (2016) 5(11): 867-876

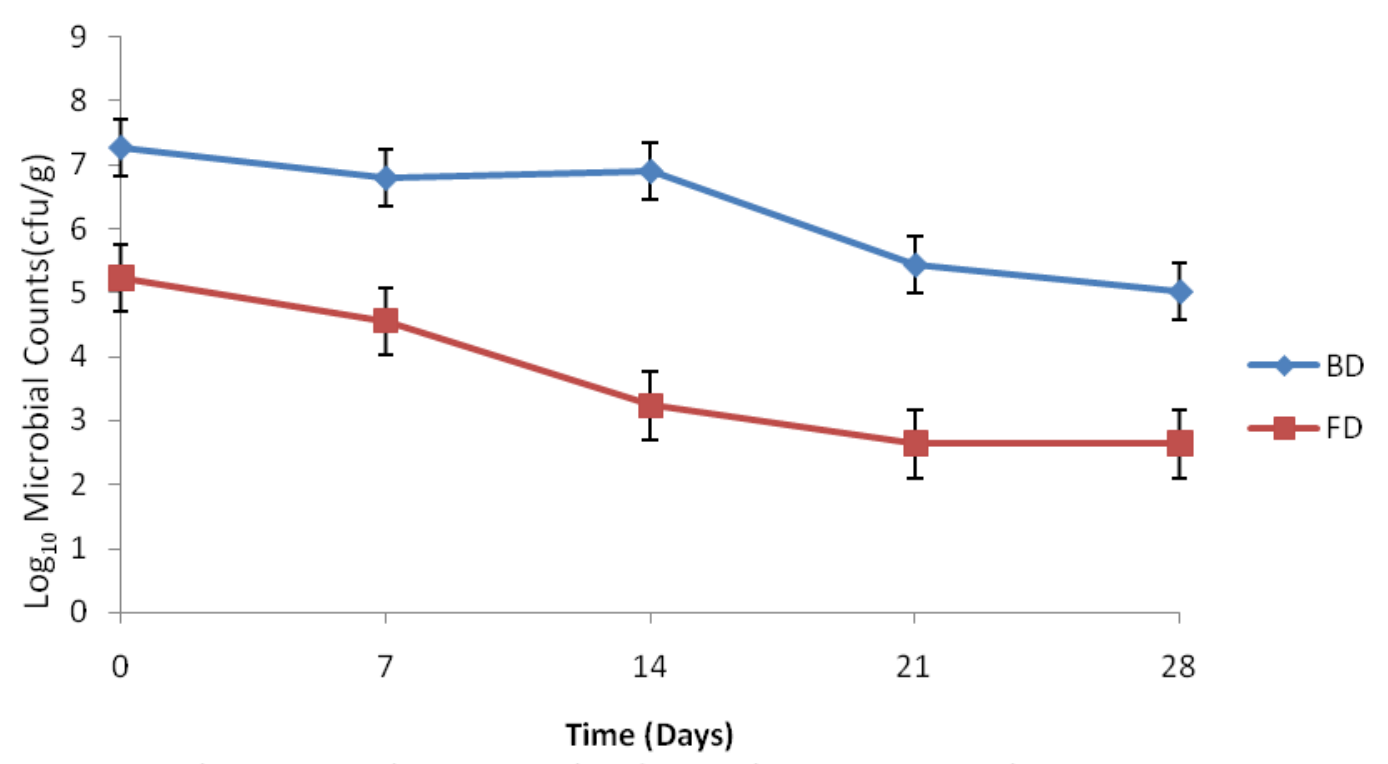

Fig. 4: Total Heterotrophic Bacterial and Fungal Counts in Sample D

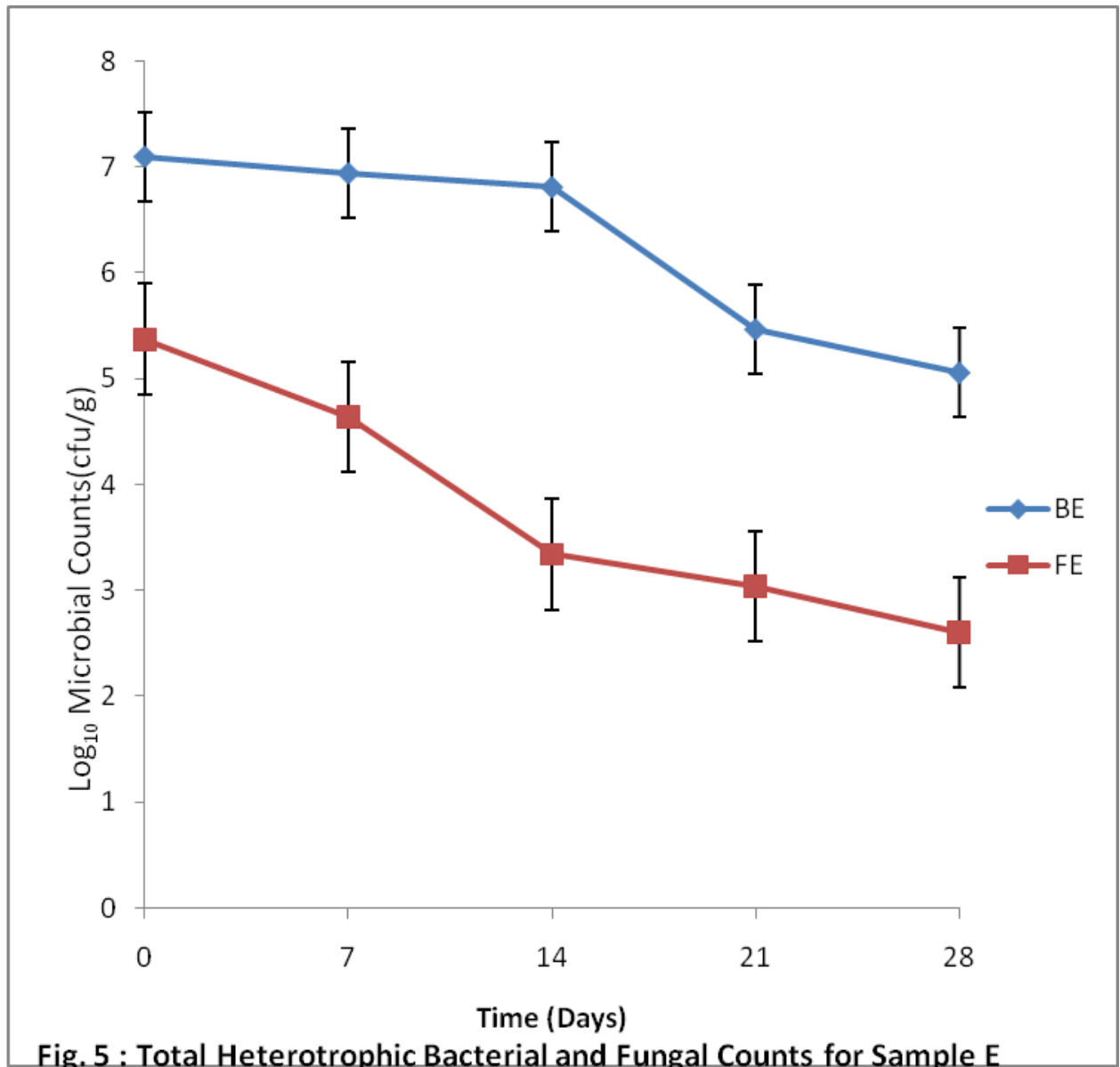




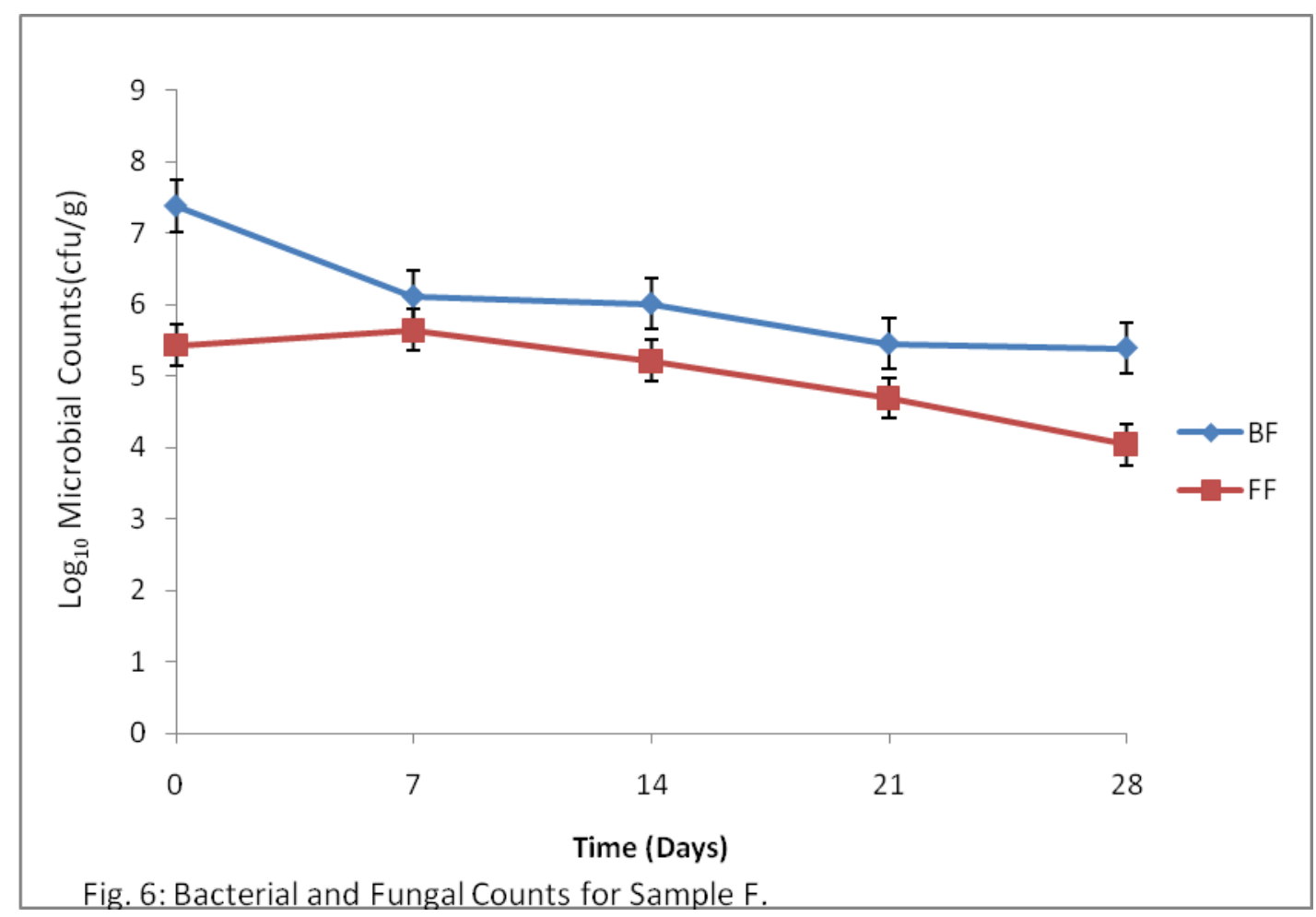

However, the toxicant was observed to be highly toxic to Penicillium sp, Mucor sp, Cladosporium sp, and Rhizopus sp. Previous researchers, showed that when heavy metals like $\mathrm{Pb}, \mathrm{Cd}, \mathrm{Ni}$ and $\mathrm{Cr}$ are available at higher concentrations in bioavailable forms they become inhibitory to fungal communities (Baldrian, 2003). Inhibitory effect of the heavy metals to the fungi population may be due to their use of extracellular enzymes required for their nutrition (Baldrian, 2009).

In conclusion, the results of this research indicate that the fungal populations were the most sensitive and affected by the toxicant introduced into the soil. A drastic reduction in fungal population and diversity was observed throughout the study period. Hence, the toxicant concentrations were inhibitory to the fungal populations rather than stimulatory. Out of the six genera of fungi isolated only two genera: Aspergillus and Fusarium were resistant in all concentrations. The bacterial populations tend to increase even with increase in toxicant concentrations, which means the bacterial communities were more resistant. It is important to note that, continuous disposal of batteries into the soil environment can cause detrimental effects, not only to man, but also to other living things and the microbial populations on which other life forms depends for their activities. This could in turn bring about ecological imbalance, retard decomposition processes and other biochemical and metabolic activities carried out in the soil by these organisms.

\section{References}

Babu, B., Parande, A. and Basha, C. 2007. Electrical and Electronic Waste: A Global Environmental Problem. Waste Management \& Res., 25: 307 - 318

Baldrian, P. 2003. Interactions of heavy metals with white-rot fungi Enzyme. Microbial Technol., 32: 78-91.

Baldrian, P. 2010. Effect of Heavy Metals on Saprotrophic Soil Fungi. Soil Heavy Metals, 19: 263 - 279. 
Douglas, S.I. and Green, D.I. 2015. Microbial Communities Found in Diesel Contaminated Soil. Int. J. Physical \& Applied Sci., 2(4): 38 - 48.

Frost and Sullivan. 2004a. World Stationary Lead Acid Battery Markets. Research Overview. Retrieved $10^{\text {th }}$ October, 2016.

http://www.frost.com/prod/servlet/rep ortoverview.pag?repid=A7140100000 $0 \&$ title $=$ Research + Overview

Green, I.T. 2005. Sustainable Information Technology. Batteries For It Systems in Buildings, Environ. Issues. 1 - 12

Holt, J.G., N.R. Kreig, P.H.A. Sneath, J.T. Stanley and S.T. Stanley. 1994. Bergey's Manual of Determinative Bacteriology. Baltimore, USA; William and Wilkins.

Jastrzbska, E. 2006. The effects of contamination with fungicides on microorganisms'counts. Pollution $J$. Natural Sci., 21 (20): 487-498.

Landi, 1., Badalucco, L. Pamare, F. and Namipieri, P. 1993. Effectiveness of antibiotic to distinguish the contribution of fungi and bacteria to net nitrogen mineralization, nitrification and respiration. Soil biology and biochemistry Pergamum press, Great Britain, pp.17-71.

Manhart, A., Osibanjo, O., Aderinto and Prakash, S. 2011. Informal e-waste Management in Lagos, Nigeria-Socioeconomic impacts and feasibility of International recycling cooperations. Final Reports of Components of the UNEP SBC E-waste Africa project.

Mohan, R.A. and Chaithanya, S.M. 2015. E- waste generation and its Management. A Review. Int. J. Adv. Technol. Engineering \& Sci., 3(1): 468 - 480

Obire, O., E.C. Anyanwu and R.N. Okigbo 2008. Saprophytic and crude oil degrading fungi from cow dung and poultry droppings as bioremediating agents. J. Agri. Technol., 4 (92): 8189.

Odokuma, L.O. and Ijeomah, S.O. 2003. Tolerance of Bacteria to Toxicity of Heavy metals in The New Calabar River. Global J. Environ. Sci., 2(2): $128-132$.

Odokuma, L.O. and Oliwe, S.I. 2003. Toxicity of substituted benzene derivatives to four chemolithotropic bacteria isolates from New Calabar River, Nigeria. Global J. Environ. Sci., 2(2): $72-76$.

Odokuma, L.O. and Akponah, E. 2010. Effect of Nutrient Supplementation on biodegradation and metal uptake by three bacteria in crude oil impacted fresh and brackish waters of the Niger Delta. J. cell and animal boil., (1): 118.

Rangaswami, G. 2004. Agricultural Microbiol., Prentice Hall of India. 4(2): 103-110.

Sosak-Swiderska, B. 2010. Effect of heavy metals on soil fungi. EGU General Assembly 2010, held 2-7 $7^{\text {th }}$ May, 2010 in Vienna, Austria. Geophysical Res. Abstracts, 12: 14357.

Spain, A. 2003. Implications of Microbial Heavy metal Tolerance in the Environment. Reviews in Undergraduate Res., 2: 1- 6.

\section{How to cite this article:}

Douglas, Salome Ibietela and Nwachukwu, Eucharia Uche. 2016. Effect of Spent Laptop Battery Waste on Soil Microorganisms. Int.J.Curr.Microbiol.App.Sci. 5(11): 867-876. doi: http://dx.doi.org/10.20546/ijcmas.2016.511.099 